\title{
Are Diversity Programs Merely Ceremonial? Evidence-Free Institutionalization
}

\section{Citation}

Dobbin, Frank, and Alexandra Kalev. 2017. Are Diversity Programs Merely Ceremonial?

Evidence-Free Institutionalization. In The SAGE Handbook of Organizational Institutionalism, ed. Royston Greenwood, Christine Oliver, Thomas B. Lawrence and Renate E. Meyer, 808-828. Thousand Oaks, CA: SAGE.

\section{Permanent link}

http://nrs.harvard.edu/urn-3:HUL.InstRepos:41288171

\section{Terms of Use}

This article was downloaded from Harvard University's DASH repository, WARNING: This file should NOT have been available for downloading from Harvard University's DASH repository.

\section{Share Your Story}

The Harvard community has made this article openly available.

Please share how this access benefits you. Submit a story.

Accessibility 


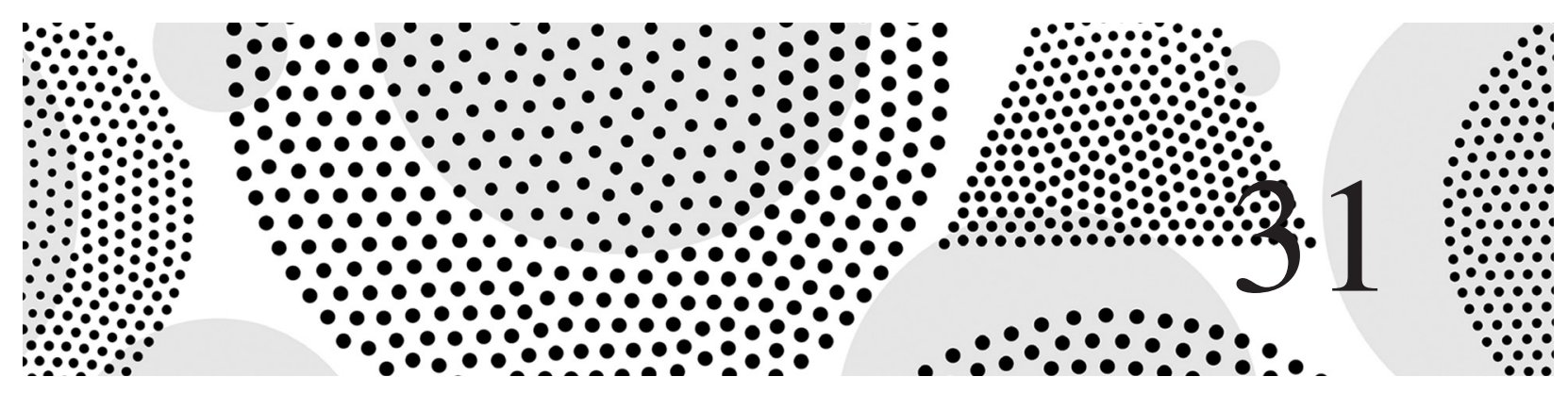

\title{
Are Diversity Programs Merely Ceremonial? Evidence-Free Institutionalization
}

\author{
Frank Dobbin and Alexandra Kalev
}

Institutionalists describe large domains of corporate policy and practice as symbolic. The work of entire departments is carried out to convey a firm's commitment to efficiency (the now dismantled strategic planning unit) or to fairness (the Chief Diversity Officer and her cadre). Executives may deliberately choose purely symbolic policies that will not alter proven routines or traditions that employees hold dear. What distinguished institutional theory, from the start, was the recognition that while organizational practices are often ceremonial, they may nonetheless serve the very material purpose of conferring legitimacy on the firm, which helps executives to raise capital, win customers and attract talent.

Institutionalists have been interested in the rise and spread of corporate equal opportunity innovations precisely because they viewed those innovations as ceremonial. The performance rating system gives the human resources office the stamp of meritocracy, even if research shows that that raters favor white men. Formal hiring guidelines make the firm appear to be operating on principles of bureaucracy, not bias, even if we know that managers often circumvent guidelines to hire their cronies. From the start, new institutionalists have described such practices as window-dressing, adopted largely to win legitimacy: 'Employees, applicants, managers, trustees, and governmental agencies are predisposed to trust the hiring practices of organizations that follow legitimated procedures - such as equal opportunity programs' (Meyer and Rowan, 1977: 349).

Nonet and Selznick (1978) tell us that firms often adopt programs that symbolize conformity with new social norms when they have not yet made substantive changes. Meyer and Rowan (1977) and Edelman (1990, 1992) suggest that firms adopt policies to symbolize their commitment instead of making substantive changes. In describing diversity practices as symbolic, institutionalists suggest that innovations are put into place for show, rather than to actually 
promote equality of opportunity. The fact that executives have rarely embraced equal opportunity programs without pressure from social movements, regulators, or professional groups has led institutionalists to speculate that their hearts aren't in it.

We report from an outpost of new institutionalists that has begun to go beyond speculation about when equal opportunity innovations have real effects. Some of us have documented the effects of diversity programs in studies using intensive data from individual firms, through field experiments (Kelly et al., 2011) or analyses of archival personnel data (Castilla and Benard, 2010; Fernandez and Fernandez-Mateo, 2006). These scholars are part of a wider movement of social scientists who look at the effects of institutional innovations on such organizational outcomes as profitability and share price, and who are advancing evidence-based approaches to understanding the effects of organizational innovations (e.g., Jung and Dobbin, 2016; Pernell et al., forthcoming; Yermack, 1996; Zuckerman, 1999).

We make a novel argument about the relationship between the intentions of innovation adopters and the effects of those innovations. The 'symbolic compliance' (Edelman, 1990; Meyer and Rowan, 1977) literature suggests that executives knowingly adopt innovations that symbolize new goals such as equal opportunity, but that have no real effects. We suggest, instead, that groups develop myths of causality about innovations but rarely put those myths to empirical tests. Management myths are rarely tested, and when they are, they may be impervious to disconfirming evidence. Thus the myth that employees are best motivated with financial incentives remains strong, despite substantial evidence that incentives can prevent people from internalizing organizational goals (Pfeffer and Sutton, 2006). The myth that diversity training reduces bias, and promotes workforce diversity, remains strong despite hundreds of studies finding that bias is resistant to training (Paluck and Green, 2009).
If institutionalists are correct in arguing that executives adopt certain diversity programs to curry favor with the public, in full confidence that those programs will fail, those executives would have to know which programs work and which do not. Research shows some diversity innovations to be effective, and others to be useless or counter-productive. But our survey suggests that even ardent advocates of equal opportunity do not know which are which. Women in leadership, crusading regulators and liberal litigators have no idea what works. Thus one study shows that women in corporate management champion diversity practices that research has shown to be ineffective, such as diversity training, and neglect practices that typically work, such as mentoring (Dobbin et al., 2011; Dobbin et al., 2015). Others find that in negotiating discrimination suit settlements, liberal federal litigators ask for ineffective diversity practices but not for effective practices (Hegewisch et al., 2011; Schlanger and Kim, 2014). If women managers and federal litigators advocating for change do not know which innovations work and which don't, neither, we suggest, do corporate policy-makers.

We have arrived at this situation because, as institutionalists have been arguing, innovations diffuse based not so much on evidence as on 'theorization' (Davis and Greve, 1997; Johnson et al., 2006; Strang, 2010; Strang and Meyer. 1993). A good theory of how an innovation functions is all you need to get firms to buy in. Once institutionalized, the prevalence of a practice in leading organizations is taken to be proof that it must be effective (Meyer and Rowan, 1977). Thus today, unconscious bias training is all the rage because Google and Facebook are doing it - two companies with alarmingly low levels of diversity in management and tech positions according to their own widely publicized statistics. ${ }^{1}$ Based on the evidence, if there are two companies that you should not emulate to promote diversity they are Google and Facebook. The paradox underlying the 
symbolic-adoption argument, then, is that if managers rely on theorization alone to determine the efficacy of a practice, their efforts to make mere symbolic efforts may backfire. While some practices are 'theorized' to have merely symbolic value (posting an equal opportunity statement) and others are 'theorized' to work (mandatory diversity training), practitioners do not know which really work (spoiler: neither works). Thus institutional theorists need to focus not only on whether innovations are theorized to have symbolic or substantive effects, but on the decoupling of means and ends (Bromley and Powell, 2012). This means we must examine the real-world evidence about the substantive effects of different innovations.

Next we review the literature on how diversity management institutions arose and diffused across US workplaces to demonstrate that the practices that diffused were championed by genuine advocates for workforce diversity. They were advocated by professional human resources and diversity managers, women in corporate management, and liberal federal officials and judges. These groups often got the innovations they wanted. They generally favored practices designed to stop bias through education, feedback or bureaucratic controls to quash managerial bias, such as mandatory job tests, formal performance ratings and grievance procedures.

After discussing the role of activists in promoting corporate change, we review evidence about the efficacy of three broad approaches to promoting diversity. We consider predictions from social science theories about the effects of management practices. These predictions often conflict with the managerial theories that are used to popularize innovations, such as the theory that anti-bias training can reduce bias. Thus job-autonomy and self-determination theories suggest that bias-control efforts, including training and bureaucratic controls, will backfire by sparking managerial resistance. Research confirms this expectation. By contrast, cognitive dissonance and self-perception theories suggest that innovations designed to put managers in charge of promoting diversity will increase commitment and lead to change. Studies confirm that mentoring programs, special college recruitment programs and in-house management training programs have substantial positive effects on managerial diversity. Finally, accountability theory suggests that when corporate officials charged with hiring, promotion and pay decisions feel accountable to others, they will scrutinize their own behavior for signs of bias, and make personnel decisions based on evidence rather than stereotypes. Studies show that diversity taskforces, diversity managers and federal regulators activate 'evaluation apprehension' on the part of managers making personnel decisions, and thereby promote workforce diversity.

One of our goals is to provide a model of how organizational institutionalists might make their work even more relevant to managers by exploring what makes innovations effective. Thus, we demonstrate that, when coupled with performance measures, the kind of organizational diffusion data that institutionalists collect can help to determine the effects of innovations.

\section{WHAT DIVERSITY ACTIVISTS WANTED}

That employer recruitment, hiring, promotion, discharge and pay practices have been revolutionized since the 1960s is not in doubt. But why? Most analysts trace the rise of new practices designed to promote workforce diversity to the civil rights and women's movements of the 1950s and 1960s, and to the expansion of federal anti-discrimination regulation, notably John F. Kennedy's Executive Order 10925 from 1961, the Equal Pay Act of 1963 and the Civil Rights Act of 1964, signed by Lyndon Johnson the year after Kennedy was assassinated (Dobbin, 2009; Nelson and Bridges, 1999).

Why did the legislation unleash two generations of constant innovation in human resources practices? Because affirmative action and equal 
opportunity policies did not specify the terms of compliance, they left the door open to institutional entrepreneurs who created one wave after another of innovations, and who continue today apace. We detail findings from the research in this domain, which point to the entrepreneurs at the heart of this revolution and their allies in government and in corporations.

Corporate leaders in the United States have reached broad consensus on how to achieve equality of opportunity. That consensus revolves around a set of employer policies and programs that are widespread among leading firms (Dobbin, 2009), inscribed in federal 'best practices' lists (Kalev et al., 2006), and required by discrimination suit settlements negotiated by federal litigators and approved by federal judges (Schlanger and Kim, 2014). For the purposes of our argument - that employers could not have deliberately adopted ineffective diversity practices because they knew not which were effective - we trace the research on who was behind these innovations. The people who helped to diffuse these innovations were on a mission. But because they wrote their wish lists in an evidentiary vacuum, they often championed innovations that did not work. After detailing who pushed these innovations, we turn to research on the efficacy of different types of equal opportunity and diversity innovations. We show that some innovations that have been described as largely symbolic, such as diversity managers and diversity taskforces (Edelman and Petterson, 1999), are highly effective, while others that are costly or disruptive, such as diversity training, diversity score cards and networking programs, are not effective. We outline a three-part theory for predicting which innovations will be effective in this domain based in the evidence.

\section{Crusaders in Personnel Management}

Equal opportunity legislation and presidential affirmative-action orders left substantial latitude to employers to devise compliance measures. Here we review the literature on the forces that promoted compliance to make a simple point. Proponents of change were civil rights crusaders, and saw the innovations they were championing as weapons for putting an end to discrimination. Those who brought change to firms were not seeking mere symbolic compliance with the law. While some of the innovations they championed did not make the cut - the courts quickly ruled against quotas - crusaders often got what they wanted. As we argue below, neither the cheerleaders for change, nor the executives who went along kicking and screaming, knew which practices actually promoted diversity. So neither group could game the system. This understanding challenges the view that firms deliberately adopt ineffectual diversity innovations for the purpose of symbolic compliance. Instead, we suggest, key groups on both sides of the issue work with a common set of theories of what works that were, until recently, untested.

Uncertainty over how to comply with Kennedy's 1961 requirement that federal contractors take 'affirmative action' to end discrimination led contractors to band together and devise strategies, at first through the semi-public Plans for Progress group (Edelman, 1990; Graham, 1990). Then, when Title VII of the Civil Rights Act of 1964 prohibited employment discrimination at all private firms, Congress left the details of compliance to employers and the courts, choosing not to create a regulatory agency with independent authority to set compliance standards (Chen, 2009). Ambiguity in both laws thus stimulated 'endogenous' compliance, whereby the regulated helped to define compliance (Edelman et al., 1999). Executives perceived the law as a moving target, and the biggest employers hired full-time equal opportunity experts to track changes in the law and in judicial interpretation.

Personnel experts took charge of designing compliance systems. Lawyers might well have taken over, however their professional 
modus operandi was not to speculate wildly about what the courts would accept as compliance initiatives, but rather to come in on the back end of the problem, when suits had been filed and employers needed representation (Dobbin and Kelly, 2007).

The field of personnel management had been dominated by white men who had made careers in resisting, or negotiating with, unions. As unions declined and as the discipline came to focus on civil rights, women took over (Dobbin, 2009: 171). Personnel specialists grew tenfold between 1960 and 2000, while the labor force grew only threefold. Women were nearly unknown in personnel as of 1960, but they held half of specialist and manager jobs by 1980 , and 70\% by the late 1990s (Dobbin, 2009: 5, 169; Roos and Manley, 1996). This change in the profession's composition shaped its agenda, and corporate policies supporting gender equality came to take precedence. In the early 1970s, for instance, federal law did not require employers to offer maternity leave, but corporate personnel offices began to create programs. Thanks in large measure to the advocacy of women in personnel management, firms offering maternity leave nearly tripled between 1969 and 1978 - but not until 1993 did Congress mandate it (Bureau of National Affairs, 1975; Kamerman et al., 1983; Ruhm and Teague, 1997).

Women in personnel also fought to keep and expand equal opportunity programs in the face of the Reagan-era retrenchment of civil rights laws. From the early 1970s, experts had argued that equal opportunity was good for business (Boyle, 1973: 95; Edelman et al., 2001). When Reagan appointed Clarence Thomas to head the Equal Employment Opportunity Commission and announced plans to bring an end to affirmative action in employment, personnel experts rebranded their efforts as part of a new 'diversity management' program to create 'strategic advantage by helping members of diverse groups perform to their potential' (Conference Board, 1992: 11). Personnel experts picked up where the civil rights and women's movements had left off.

As personnel departments took charge of diversity management, and became dominated by women, the profession became the leading local advocate of diversity programs in most companies; firms with human resources departments, diversity staff and HR consultants became significantly more likely than their peers to adopt a range of different diversity measures (Dobbin et al., 1993, Dobbin and Kelly, 2007; Edelman, 1990, 1992).

\section{Crusading Women Executives}

Corporate diversity innovations were championed not only by human resources experts, but by women and minorities within firms. Surveys have long shown that these groups favor diversity programs. Bobo and Kluegel (1993) find that blacks are significantly more supportive than whites of opportunity enhancement policies, and white women are more supportive than white men. Cohen and Huffman (2007) report that in the 1996 General Social Survey, women managers were 1.3 times as likely as men to agree that 'employers should make special efforts to hire and promote qualified women'. Decades of research show, Steeh and Krysan (1996) conclude, that blacks are consistently more supportive of government aid for minorities and of hiring preferences.

It is no surprise, then, that when women gain ground in firms they advocate for diversity programs. Employers with more women are more likely to offer flexible work arrangements and childcare centers (Deitch and Huffman, 2001) and sexual harassment programs (Dobbin and Kelly, 2007). The support of women managers for diversity programs more generally (Dobbin et al., 2011) may help to explain the continuing popularity of diversity programs even after regulatory activity was cut back in the early 1980s, for women continued to gain 
ground in management through the 1990s (Anderson, 1996; Edelman et al., 2001; Kelly and Dobbin, 1998; Leonard, 1990).

One piece of evidence in support of our contention that corporate adoption of diversity programs that serve purely symbolic purposes is not entirely deliberate is that women executives often support policies that do not work. Quantitative studies show that they encourage the adoption of one program that has been shown to promote diversity taskforces - but also three programs that have been shown to be ineffective - EEO advertisements, diversity training for managers and diversity training for non-managers. They do not help to spread mentoring programs, which are highly effective (Dobbin et al., 2007; Dobbin et al., 2011; Edelman and Petterson, 1999).

\section{Crusading Officials and Liberal Judges}

Kennedy's 1961 affirmative action order (Executive Order 10925, 26 Fed. Reg. 1961) requiring federal contractors to end discrimination in employment stimulated extensive private-sector action, through the semi-public Plans for Progress group of federal contractors (Dobbin, 2009: 13). Contractors soon wrote non-discrimination policies of their own, changed their personnel manuals and announced in job advertisements that they were 'Equal Opportunity Employers' (Dobbin et al., 1993; Edelman, 1992).

By most accounts, the Civil Rights Act did not require specific hiring and promotion practices, or give the executive branch that power, because the bill's sponsors sought the votes of moderates (Chen, 2009; Graham, 1990). Hence compliance was a moving target because local, state and federal judges and regulators could weigh in on standards. The regulatory system was 'porous', in that citizens could appeal to various public authorities to interpret and reinterpret laws (Kelly, 2003; Lieberman, 2002).
In the 1960s and 1970s, the people drawn to work at the agencies overseeing the Civil Rights Act and presidential affirmative-action orders, the Equal Employment Opportunity Commission (EEOC) and Office of Federal Contract Compliance Programs (OFCCP), respectively, were mostly champions of change (Blumrosen, 1993). The federal judiciary was largely liberal. In the 1980s, Reagan appointed conservatives to those agencies - Clarence Thomas headed the EEOC from 1982 to 1990 - but it took Reagan many years to change the judiciary. EEOC litigation and investigation of complaints, and OFCCP compliance reviews of federal contractors, have been shown to promote the use of a number of different diversity programs (Edelman, 1992). Litigation and compliance reviews also led to increases in workforce diversity, although compliance reviews became ineffective in the Reagan years (Kalev and Dobbin, 2006). While Reagan appointees did not enforce the law vigorously, corporate reforms that had begun to spread, such as diversity training, continued to grow in popularity (Dobbin and Kelly, 2007; Dobbin and Sutton, 1998; Edelman, 1990, 1992; Kelly and Dobbin, 1999).

Federal agencies appear to have reduced pressure on employers during the 1980s. But the people who championed specific corporate diversity policies were proponents of change, not foot-draggers. When employers embraced innovations, they embraced those championed by crusaders. When conservatives controlled the executive branch they did not lobby for change, and thus when federal regulators did lobby firms, they advocated programs the left believed in. Liberal EEOC regulators recommended practices popular among leading employers ${ }^{2}$ in the belief that those employers know what they are doing. Conservative judges rarely vetted diversity innovations, and liberal judges vetted innovations they expected to expand opportunity. Thus for instance liberal regulators and judges alike moved toward defining discrimination against pregnant workers as prohibited under 
Title VII, encouraging firms to offer maternity leave long before Congress required it in 1993 (Kelly and Dobbin, 1999). As Guthrie and Roth (1999) show, liberal justices played a key role in promoting corporate work-family programs. Liberal judges also backed corporate anti-harassment policies, training and complaint systems (Dobbin and Kelly, 2007). Liberal regulators and judges actively promoted corporate innovations they expected to work.

Perhaps the best evidence that officials with the best of intentions promoted the wrong policies comes from studies of the behavior of career civil rights litigators representing plaintiffs. When discrimination suits are being settled, those litigators negotiate over terms. Thus private litigators, and litigators for the EEOC, have a say in what goes into agreements. Some settlements include only monetary awards, but large class action settlements usually include program changes ('injunctive relief'), in the form of antidiscrimination initiatives. The most common programmatic changes are posted equal opportunity policy (86\%), equal opportunity training $(87 \%)$, written anti-discrimination policy (33\%) and civil rights grievance system (32\%) (Schlanger and Kim, 2014: 1573). However, we show below that these initiatives have either no effect (true for policy posting and creation) or adverse effects (true for equal opportunity training and grievance system). In fact, none of the organizational initiatives found with any regularity in these settlements shows a positive effect on workforce diversity. A study of major consent decrees in discrimination cases concluded that settlements specify programmatic changes that have been shown to have little or no effect (Hegewisch et al., 2011). Do career civil rights litigators working for plaintiffs deliberately sabotage agreements? We suggest that like everyone else, they have no idea what works.

If diversity managers, women in management and liberal officials and judges promote diversity programs that do not increase diversity then we may need to understand policy failure as the consequence of a mismatch between means and ends (Bromley and Powell, 2012). By theorizing how new innovations work, management gurus give executives tools for achieving goals. But if their theorizations are flawed, and are never tested with evidence, innovations that are ineffective or counter-productive may prevail. Programs adopted with the best of intentions may not be effective, but may survive. This may explain why many American firms with elaborate diversity initiatives have made little progress in promoting diversity since the 1980s. Below we explore which diversity practices work and which fail. We offer a theory to explain these differences.

\section{ARE DIVERSITY PROGRAMS MERELY CEREMONIAL?}

Our core argument is that because no one has known which corporate diversity innovations have only symbolic value, executives who were secretly opposed to diversity could not systematically choose interventions that did not work. We have been arguing that the people who chose diversity measures were, by and large, advocates for change, and that even these advocates mostly chose ineffective measures. They were human resources managers who had been attracted by the field's civil rights mission, women who rose to management positions and liberal litigators and judges. We suggest that their core strategy of trying to control managerial bias through training, feedback and bureaucratic measures is wrong-headed. Next we review research on the effects of corporate anti-discrimination programs to assess which broad approaches work and which do not. Are diversity programs merely ceremonial? Some are. Some aren't. The control strategies we begin with are, for the average firm, worse than ceremonial - they have adverse effects on actual workforce diversity. 


\section{Bias Control}

Everything we know from psychological and sociological studies of work suggests that efforts to control managerial bias through rules and rehabilitation will fail. Jobautonomy theorists in sociology and selfdetermination theorists in psychology tell us that such control strategies typically backfire. In the job autonomy literature, intrusive controls on workers predict job dissatisfaction and failure to perform (Hodson, 1996; Judge et al., 2001; Lamont, 2000). Lacking autonomy, workers often try to assert control through sabotage, goldbricking and resistance (Gouldner, 1954; Hodson, 1991a, 1991b; Roy, 1952). The self-determination literature shows that people respond to constraints and efforts to influence their decisions by rebelling to reassert personal control (Brehm and Brehm, 1981; Silvia, 2005). Studies of bias control confirm the general principle: whites resist external controls on racial prejudice (Galinsky and Moskowitz, 2000; Plant and Devine, 2001).

Diversity training and feedback comprise one control strategy, designed on the principle of thought control. Stereotyping is a natural cognitive mechanism, the thinking goes, but the associations we make between race, gender and workplace performance can have the effect of sustaining inequality (Gorman, 2005; Kanter, 1977; Lemm and Banaji, 1999). Since the 1960s, federal agencies such as the Social Security Administration and private companies such as General Electric have tried to give employees the tools to control their own biases. Diversity training is supposed to make managers aware of their own biases, and diversity performance ratings are supposed to provide them with feedback on their behavior (Bendick et al., 1998; Shaeffer, 1973). Anti-bias training is based in the intuition that knowledge about members of other groups, and an understanding of stereotyping, may reduce discrimination (Fiske, 1998; Nelson et al., 1996). Diversity performance evaluations are based on the intuition that feedback can influence managerial attention and motivation (Reskin, 2003: 325), and that accountability can reduce bias (Tetlock, 1985). Resistance has been documented in a number of studies. They suggest that anti-bias training can activate rather than suppress bias (Kidder et al., 2004; Naff and Kellough, 2003; Rynes and Rosen, 1995; Sidanius et al., 2001). A review of over 900 anti-bias interventions finds that most have weak effects, and some backfire (Paluck and Green, 2009). For instance, when white subjects read anti-prejudice materials and feel pressured to agree, their anti-black prejudice increases (Legault et al., 2011).

Rules that govern personnel decisions represent a second control strategy for quashing bias. Early on, personnel managers built bureaucratic anti-discrimination practices, such as formal performance evaluations and civil rights grievance procedures, on the foundation of policies that unions championed to shield their leaders from retaliation (Baron and Bielby, 1980; Dobbin et al., 1993; Jacoby, 1984; Kochan et al., 1994). As noted, plaintiff attorneys in discrimination suits often ask for these practices in settlements (Edelman et al., 2011; Schlanger and Kim, 2014). And social scientists have argued that employers can 'reduce attribution errors by routinely collecting concrete performance data and implementing evaluation procedures [including performance ratings] in which evaluators rely exclusively on these data' (Reskin and McBrier, 2000: 235; see also Bielby, 2000). Job tests, written performance evaluations and grievance procedures are thought to achieve this purpose.

Mandatory job tests were popularized as a means of ensuring that managers select employees based on ability, not race or gender. For management jobs, most employers use standardized paper-and-pencil tests (Berry et al., 2011). However, hiring managers may resist the formal control of job tests by administering tests selectively (Mong and Roscigno, 2010: 10; Puma, 1966). Studies suggest that managers sometimes require only minority applicants to take tests (Purcell, 
1953 ) or ignore test results that do not reinforce stereotypes (Rivera, 2015).

HR experts argue that quantitative performance rating systems can also quash bias, when firms tie promotions, pay and layoffs to employee scores. Yet managerial resistance against performance evaluations designed to control pay and promotion decisions shows up in biased scores. Studies suggest that raters often prefer white men to similarly productive women and non-whites (Hamner et al., 1974; Heilman, 1995; Kraiger and Ford, 1985; Oppler et al., 1992; Pulakos et al., 1989; Roth et al., 2003; Tsui and Gutek, 1984). Meta-analyses show a persistent gap in ratings of black and white workers (McKay and McDaniel 2006, Roth et al., 2003). In firms that use mathematical formulas to link compensation to objective ratings, managers resist by interpreting scores subjectively to pay their cronies more (Castilla, 2008; Shwed and Kalev, 2014). It appears that managers try to circumvent performance rating systems to achieve their own purposes. Rules elicit rebellion.

A third control strategy is the civil rights grievance procedure, designed to rehabilitate or remove discriminatory managers. Personnel experts created quasi-judicial grievance systems modeled on union grievance procedures (Edelman et al., 2011: 919). These were designed to give workers a system for resolving complaints of discrimination within the firm, and to ensure that managers who discriminate are rehabilitated. But managers appear to rebel against grievance systems, which threaten their autonomy by opening them to rebuke (Edelman, 1992: 1543). Of nearly 90,000 discrimination complaints to the EEOC in 2015, 45\% included a charge of retaliation, suggesting that managers do not respond to grievances with neutrality, but by punishing complainants.

Studies of the effects of these programs on the share of women and minorities in management suggest that they do not work. Obligatory diversity training backfires because it signals that the company is trying to control employees' thoughts. In the average company that made training mandatory for managers, black women in management decreased by $10 \%$, and Asian American men and women decreased by $4-5 \%$, over about five years (see Figure 31.1; see Dobbin et al., 2007; Dobbin et al., 2015; Kalev et al., 2006 for details on model estimation). Making training mandatory appears to be particularly harmful; companies that made diversity

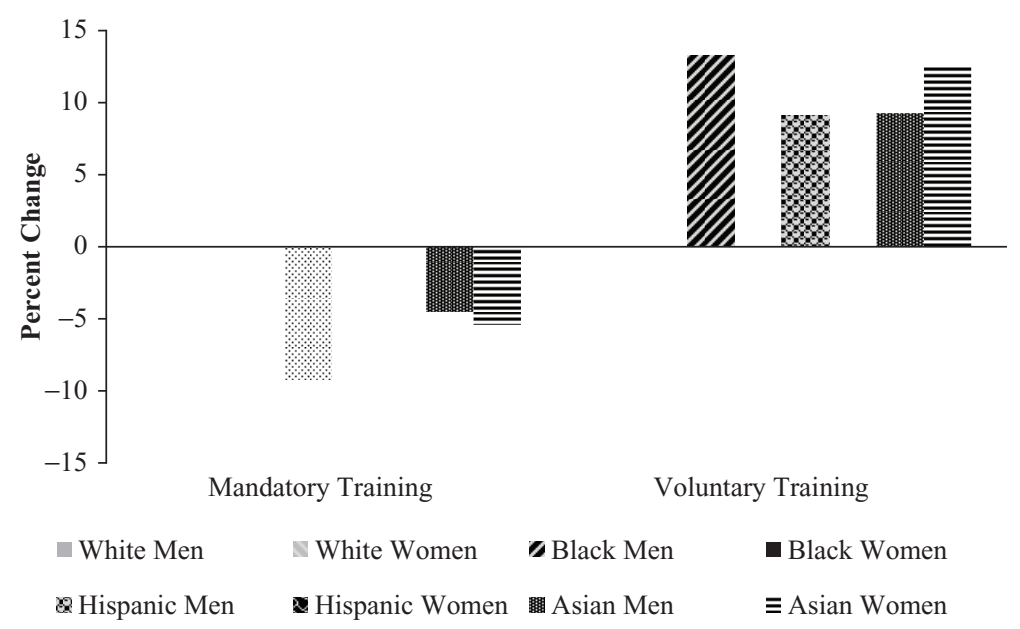

Figure 31.1 Effects of diversity training on managerial diversity 
training voluntary saw some increases in managerial diversity. Companies that provided feedback to managers on their diversity performance appear to elicit resistance as well. Those that put in diversity performance ratings for managers see no positive effects, and negative effects of $6 \%$ for black men in management. We omit this policy from the figure because only one effect is significant.

Figure 31.2 shows the effects of one bureaucratic hiring procedure designed to constrain managerial discretion and one dispute-resolution program. We argued that managerial resistance to mandatory job tests has been shown to take several forms - managers can test only some applicants, or ignore test results, for instance. Companies creating written job tests for managers - about $10 \%$ have them today - see decreases of 4-16\% in white women, black men and women, Hispanic men and women, and Asian women over the next five years. On average, companies that create performance rating systems see no change in minority managers over the next five years, and a $4 \%$ decrease in white women (we omit this policy from the figure). After companies adopt civil rights grievance systems, they see significant declines in white women managers, and all minority groups except Hispanic men, ranging from $4 \%$ to $11 \%$. This suggests that retaliation against complainants may be widespread.

These negative effects are entirely consistent with findings from the scholarly literature on job autonomy and self-determination. People resist obtrusive controls on their behavior in order to maintain autonomy in decision-making. The evidence suggests that they do so in different ways for different practices. Taken together these results point to the importance of testing managerial theories with evidence. Well-intentioned activists often backed practices that were worse than ineffective - that were counter-productive. We suggest that executives with the best of intentions could not have known that these innovations did not work. And thus that it would have been difficult for them to deliberately create anti-discrimination programs that would have only symbolic effects.

\section{Managerial Engagement}

The second broad approach championed by diversity activists and embraced by firms was

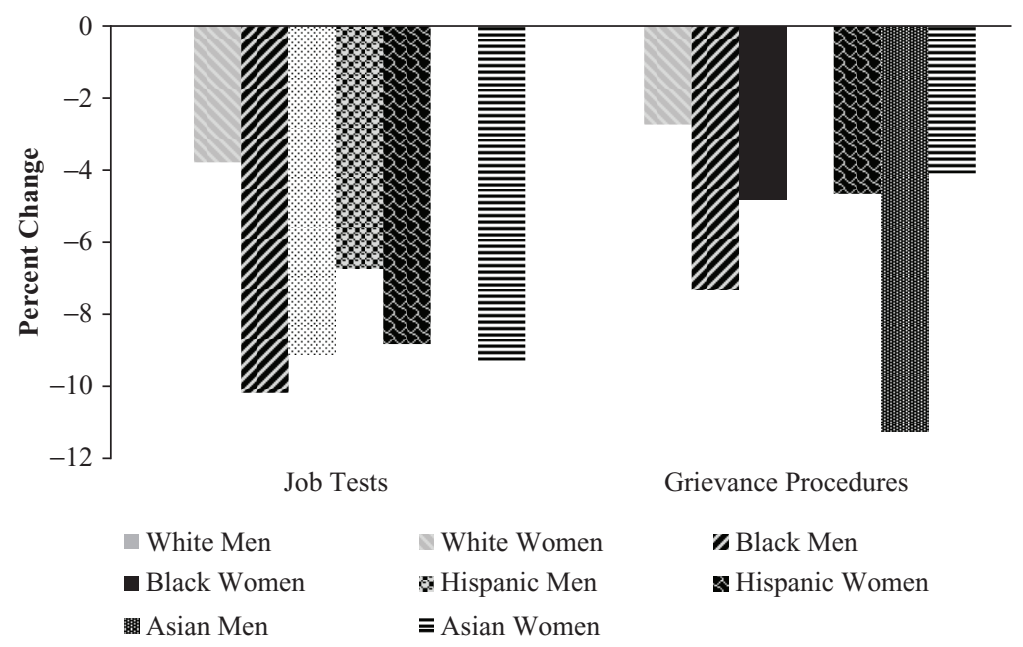

Figure 31.2 Effects of bureaucratic controls on management diversity 
to engage managers in changing the workplace through mentoring programs, special college recruitment programs for women and minorities, and skill and management training with special nomination procedures for underrepresented groups. Any of these programs could elicit the same sort of rebellion we saw for the control tactics, and indeed, some firms have been reluctant to create special recruitment and training for fear of white male backlash (Dobbin 2009). But these programs share several key characteristics that, we argue, make them effective. They are voluntary - managers are asked to sign up, and while some may be nudged, they are not required to participate. These programs encourage managers to help address the the problem rather than labeling them as the cause of the problem. And they engage managers in active problem-solving.

Cognitive-dissonance and self-perception theories suggest that by encouraging them to help solve the problem, employers help managers to think of themselves as proponents of change (Bem, 1972; Festinger, 1957; Festinger and Carlsmith, 1959; Ito et al., 2006; Mori and Mori, 2013). This approach is better aligned with the managerial modus operandi than practices that require them to follow detailed orders and seem to lay blame for inequality on them - those we just discussed. Psychologists find that when people's attitudes and behaviors are out of sync, they face internal pressure to bring the two into alignment (Cooper and Fazio, 1984; Zanna and Cooper, 1974). Festinger argued that when behavior conflicts with beliefs, people experience cognitive dissonance. If you ask someone to write an essay in support of a view they do not hold, they come to see some merits in that view. So long as executives do not twist their arms, we suggest, even managers who are cool to the idea of promoting diversity will come to support diversity through policies that engage them in positive change.

Several innovations engage managers in promoting diversity, and we suggest that participation will win them over. Mentoring programs grew in popularity in the 1980s as a way to groom talent for promotion (Roche, 1979), and diversity experts soon argued that they could provide special benefits to women and minorities (Vernon-Gerstenfeld and Burke, 1985: 67). Sociologists had argued that network contacts are key to finding jobs and moving up (Baron and Pfeffer, 1994; Granovetter, 1974), and that women and minorities often lack the ties to powerful executives that junior white men have to begin with, or develop outside of work through shared interests and activities (Burt, 1998; Ibarra, 1995; Petersen et al., 1998; Reskin and McBrier, 2000). Formal mentoring programs match junior employees with volunteer mentors, who are typically at least two rungs above them on the corporate ladder, in different departments (Neumark and Gardecki, 1996). By the early 1990s, $20-30 \%$ of big US firms had formal mentoring programs (Conference Board, 1992; Thomas, 2001). Among mid-size to large firms, about $10 \%$ had mentoring programs targeting women and minorities by 2002 (Kalev et al., 2006).

Special recruitment programs for blacks were popularized in the early 1960 s as affirmative-action measures among federal contractors (Gordon, 2000). These programs use existing managers to find minority recruits. Companies now run special recruitment programs for entry-level production and service jobs in high schools, and special programs for professionals and management-track employees at colleges. By the mid-1960s, high-profile historically black schools were drawing large numbers of recruiters (Mattison, 1965). Today, some $15 \%$ of medium and large corporations run visits to colleges to draw minorities and women to management, including Target Stores and General Mills (Dobbin et al., 2015; Rodriguez, 2007: 69).

From the early 1960s, federal contractors subject to affirmative-action regulations created in-house training systems for skilled 
jobs, supervisory positions and management jobs, and coupled these with programs to draw in minorities and women (Boyle, 1973; Holzer and Neumark, 2000). Training programs are often designed and staffed by existing managers. While the courts struck down the idea of employer-initiated hiring quotas, they accepted employer quotas for training programs (Stryker, 1996). Management training programs, in particular, typically engage current managers in training aspiring managers in the latest methods in their own fields of specialization. Companies organize these on different models depending on the geographic dispersion of their employees; those with a single large location may spread training out over months in small doses, while those whose business units are small and farflung may train in a central location, in concentrated doses. Either way, existing managers are usually integral to the training, and are often asked to nominate women and minorities for participation.

Studies show that these programs promote workforce diversity. Cross-sectional studies suggest that special college recruitment, in-house management training, and special nomination guidelines to promote women and minorities, are associated with greater workforce diversity (Holzer and Neumark, 2000; Konrad and Linnehan, 1995). Our longitudinal studies of a national sample of firms, over the course of 30 years, suggest these engagement activities typically promote diversity, even in the hard-to-change ranks of management.

First, Figure 31.3 shows that firms that institute special college recruitment for women count $10 \%$ more white women, $8 \%$ more black women, $11 \%$ more Hispanic women, and $8 \%$ more Asian American women in management after 5 years. These programs also boost black and Asian American men (Dobbin et al., 2015). Special minority recruitment programs increase black men in management by $7 \%$ and black women by $9 \%$. Second, Figure 31.4 shows that mentoring programs increase black women in management by over $15 \%$, Hispanic men by about $10 \%$, Asian Men by about $18 \%$ and Hispanic and Asian American women by over 23\% each (Dobbin et al., 2007). Third, management training programs, not shown in the tables, boost white women in management by $12 \%$, and special nomination procedures to enroll women boost white women by another $11 \%$ and Asian American men by the same amount (Dobbin et al., 2015).

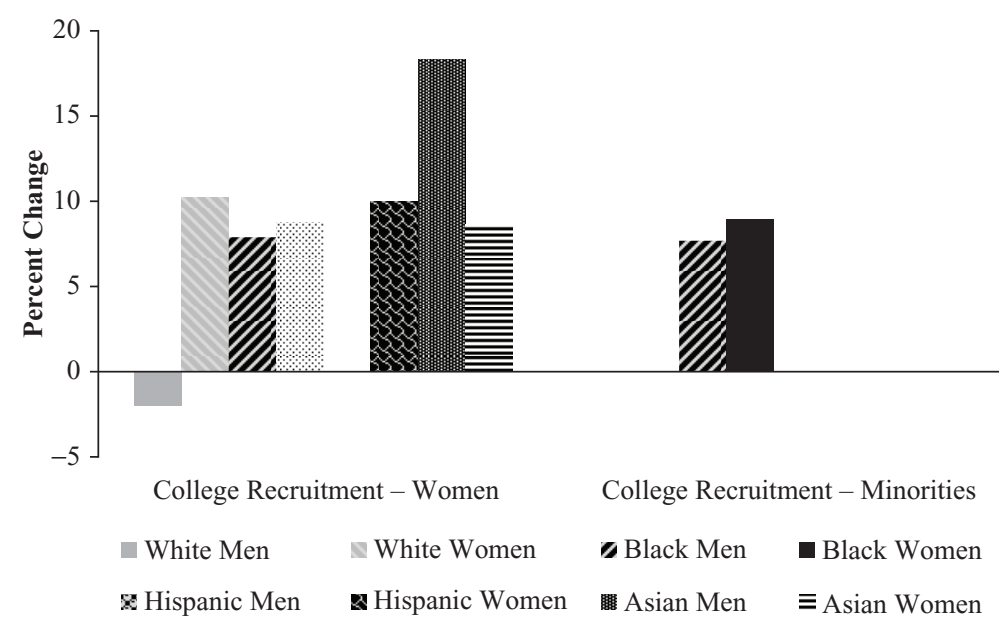

Figure 31.3 Effects of special college recruitment on management diversity 


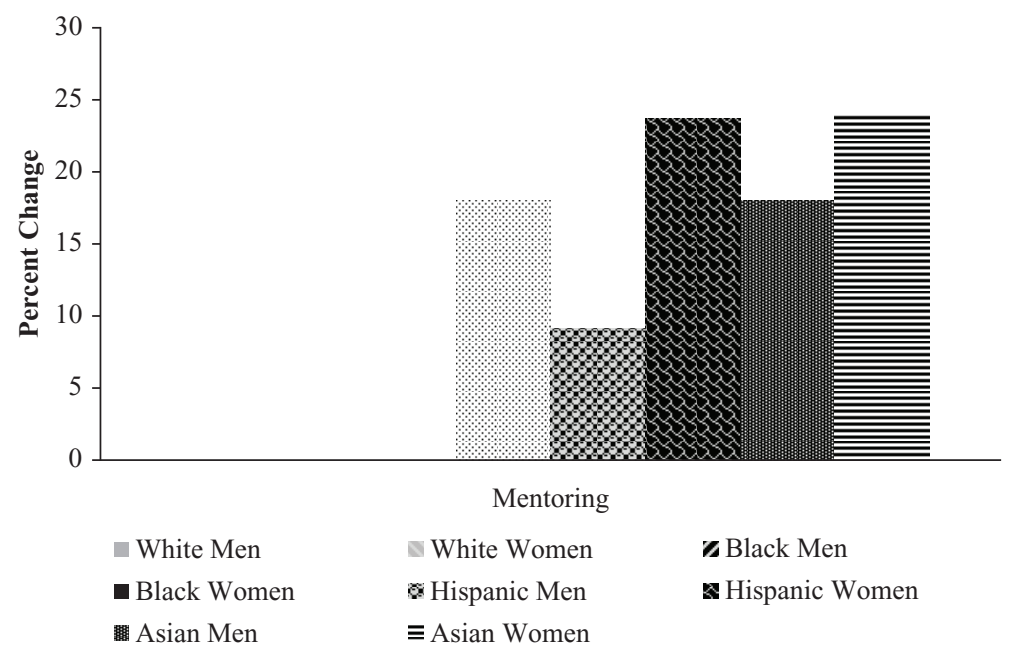

\section{Figure 31.4 Effects of mentoring on management diversity}

Just as the diversity-management literature gave executives little reason to think that control-oriented programs were counter-productive, the literature gave them little reason to think that engagement-oriented programs would work better (Dobbin, 2009). Thus well-meaning executives were clueless about which programs to adopt, as were executives hoping not to rock the boat.

\section{Social Accountability}

Institutionalists have long viewed accountability as a means of ensuring that organizational policies are carried out (Edelman, 1992). Yet, accountability mechanisms that smack of control appear to have adverse effects. Diversity report cards come off as controlling and show only negative effects. Civil rights grievance procedures hold managers accountable through an internal quasijudicial system, and have broad negative effects. The accountability literature, however, suggests that another type of accountability can have positive effects - a type we will call social accountability. What we know from social psychological studies suggests that accountability of this sort can have positive effects. If people think that others will evaluate their decision processes, they may censor their own biases. In their organizational theories of inequality, Reskin (2000) and Bielby (2000) build on accountability theory from psychology, which suggests that when people think they will be asked to account for a decision, they suppress bias (Tetlock, 1992; Lerner and Tetlock, 1999). Evaluation apprehension (Cottrell, 1972), or the concern that one's decisions will be reviewed, has been shown to reduce bias in assessments of individuals (Kruglanski and Freund, 1983).

Research suggests that several types of policies can elicit social accountability of this sort: diversity taskforces, diversity managers and federal contract oversight. In each case, managers charged with making hiring and promotion decisions know that they may be asked about those decisions. In the case of taskforces, they may be asked by taskforce members who are in their own departments. In the case of diversity managers, they may be asked when those managers review hiring, promotion and pay decisions. In the case of federal contractors, they may be asked to account for decisions during Department of Labor reviews of personnel practices and outcomes. 
The first diversity taskforces appeared in the late 1960s, in firms such as General Electric, under the banner of equal opportunity (Dobbin, 2009). Today's taskforces typically bring together higher-ups from different departments in monthly meetings, at which they scrutinize hiring, promotion, retention and pay data to identify problem areas that need solutions (Sturm, 2001). Members brainstorm for solutions to weak recruitment of minorities, or poor retention of women professionals. Taskforces create accountability because members return to their departments, and are the first to notice when new initiatives are not being carried out. Firms design taskforces to get managers involved in problem-solving, and so taskforces have the added benefit of ratcheting up managerial engagement. By 1991, the Conference Board found that a third of big US firms had taskforces (Miller, 1994). Our own 2002 survey shows that taskforces began to spread in the wider population of firms in the late 1980s (Kalev et al., 2006).

Diversity managers first appeared after Kennedy's 1961 affirmative-action order, under an array of different titles - equal opportunity specialist, affirmative action manager, minority relations executive. Studies suggest that diversity managers improve the efficacy of equity reforms by activating accountability (Castilla, 2008; Hirsh and Kmec, 2009; Kalev et al., 2006). In line with accountability theory, diversity managers report that one of their primary duties is to question managerial decisions. According to a Massachusetts electronics industry diversity manager: '[My] role is making sure that we have not overlooked anybody. [We get] pushback from managers when we have internal postings for jobs, but [my job is] making sure [the manager has] really thought through their decision. I would keep asking - why this person, why not that person?' (quoted in Dobbin and Kalev, 2015: 180-181).

Taskforces and diversity managers should elicit 'evaluation apprehension' within the firm and thereby promote diversity. We expect regulatory oversight to have similar effects. The Department of Labor's Office of Federal Contract Compliance Programs (OFCCP) conducts on-site reviews of affirmative-action compliance in federal contractors, at its discretion (Anderson, 1996). Firms with contracts or subcontracts of at least $\$ 10,000$ are subject to reviews scrutinizing personnel practices and results. It is 'evaluation apprehension', rather than the evaluation itself, that causes people to scrutinize their own behavior for signs of bias, and thus we expect federal contractors to see increases in diversity, whether or not they actually experience compliance reviews (Cottrell, 1972; Sturm, 2001).

Studies show positive effects of all three types of accountability on workforce diversity. We find that at the average company that puts in a diversity taskforce, white women and each of the minority groups grow in management by 8 to $30 \%$ over 5 years (see Figure 31.5) (Dobbin et al., 2015). Companies that appoint diversity managers see increases in white women, black men and women, Hispanic women and Asian American men and women in management ranging from $7 \%$ to $18 \%$ in the following five years. These interventions work well, but they are not common.

The effects of federal contractor status are a bit complex to show in a bar chart because they vary over time. Contractors saw betterthan-average improvements in gender and racial diversity in the 1970s (Leonard, 1989, 1990). In those years, Washington was actively conducting compliance reviews. After the Reagan administration reduced enforcement, the positive effect of federal contractor status declined (Kalev and Dobbin, 2006). Since then, winning a federal contract predicts a decline in diversity in most firms (Kalev et al., 2006). This may be because contracts ensure employment stability and thus draw applicants; Reskin and Roos (1990) find that employers discriminate in favor of white men when they have long queues of applicants. Yet federal contracts catalyze a number of 


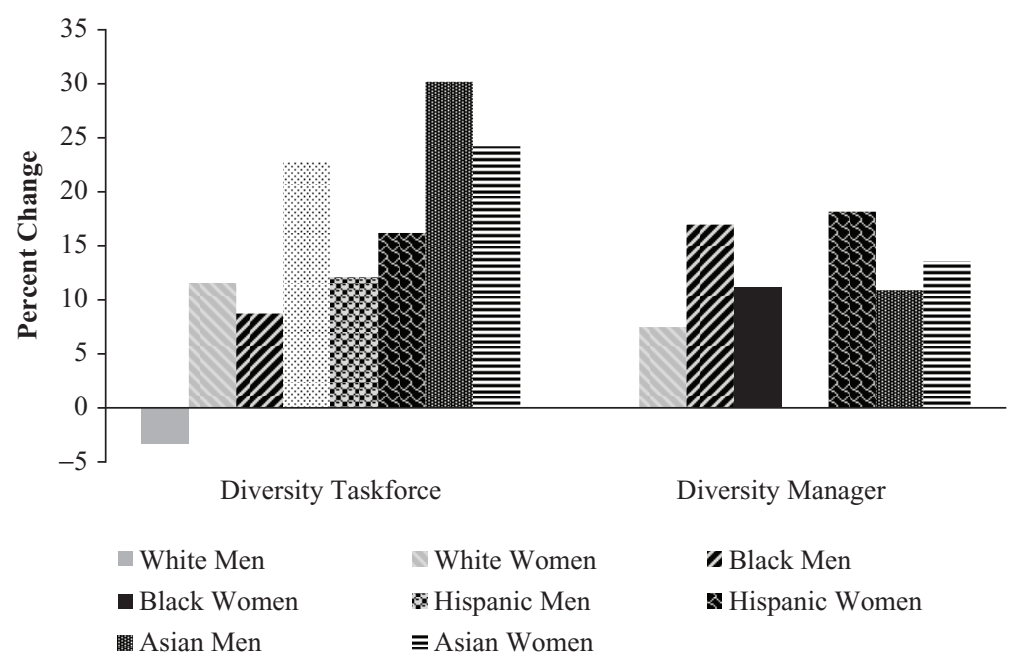

Figure 31.5 Effects of diversity taskforces and diversity managers on management diversity

equal opportunity practices in the years after the Reagan administration curtailed enforcement. In employers with federal contracts, diversity practices tend to work better due to evaluation apprehension (Kalev et al., 2006). When firms win federal contracts and managers realize that the Department of Labor may conduct inspections, for instance, the negative effects of job tests that we saw in Figure 31.2 disappear, as do all but two of the negative effects of grievance procedures (Dobbin et al., 2015).

\section{CONCLUSION}

We argue that because the effects of corporate innovations are typically based on untested theories, rather than on evidence, leaders who hope to make real change, as well as those who do not, operate in the dark. This throws a wrench into executive efforts to comply with the law by taking symbolic measures that will not affect workforce diversity. Window-dressing, or 'symbolic compliance', may have the unanticipated effect of actually changing workplaces. That is the case for diversity taskforces for instance, which many expected to generate a lot of hot air and the occasional Mexican-themed cafeteria menu. In fact, we have found, taskforces lead to substantial improvements in managerial diversity.

The flip side is that even the most ardent of diversity champions promote innovations drawing on theorization by management gurus and leading firms, rather than on hard evidence. Some of the innovations they favor backfire. Practices can diffuse widely on the basis of compelling theorization (Strang and Meyer, 1993), and may then become impervious to disconfirming evidence. It took centuries following the scientific revolution for evidence-based medicine to take hold. Evidence-based management has yet to gain a substantial following, and thus the field of management is still rife with gurus and snakeoil salesmen. Their theories often smack of science, being based loosely on concepts from economics, psychology and sociology, but their theories are rarely tested in the field, and even when they are disproven, they are rarely rejected (Pfeffer and Sutton, 2006).

Perhaps the best evidence for our argument is that the people who decided which 
diversity programs would become popular were, by and large, champions of diversity. They were women drawn to human resources management by the mission of equal opportunity, who devised race relations training, formal performance evaluations and diversity scorecards for managers. They were women and minorities who reached leadership positions in corporations and lobbied successfully to have diversity training and formal equal opportunity policies put into place. They were plaintiff litigators in discrimination suits who helped to define diversity grievance procedures, and bureaucratic hiring and promotion systems, as tools for stopping discrimination. And they were federal regulators working in agencies devoted to equality of opportunity who put such measures at the top of their 'best practices' lists.

When the civil rights movement wound down, these were the groups that carried the banner of equal opportunity forward. What companies did was defined by these groups. Yet some of the programs they championed have proven to be ineffective or counterproductive. Research from various quarters supports this conclusion. In quantitative studies, we have examined large numbers of diversity practices at once, and have largely supported the findings from various studies of individual programs, such as field and lab studies of performance rating systems (which show evidence of bias in ratings), and field and lab studies of anti-bias training (which seldom show any long-term effects, and frequently evidence increased stereotyping and resistance).

Advocates do not necessarily know whether the programs they promote are effective or not because they operate in a faith-based, evidence-free zone. The result is that both for crusaders hoping to promote equality of opportunity, and for executives who want no more than symbolic measures that will not change their workforces, diversity programs may have unintended consequences that thwart their best (or worst) intentions. This suggests that institutionalists should study not only policy-practice decoupling but also means-ends decoupling (Bromley and Powell, 2012). In the case at hand, decoupling between means and ends may have adverse effects when policies that do not have the advertised effects, such as mandatory diversity training, create managerial rebellion and crowd out other programs from the diversity budget.

The growing body of research on the effects of diversity programs provides proof of concept of a new area of research for institutionalists. Both psychologists and sociologists have begun to test the effects of diversity innovations (Castilla and Benard, 2010; Fernandez and Fernandez-Mateo, 2006; Kaiser et al., 2013), providing a foundation for an evidence-based approach to diversity management. Institutionalists typically have the ideal type of data to address questions of management efficacy. Whether they study shareholder value reforms, environmental initiatives, or diversity management, institutionalists track the spread of innovations across populations of firms, and over time. By coupling the data they use for diffusion studies with data on outcomes, such as firm performance, environmental degradation, or workforce diversity, institutionalists can examine the efficacy of innovations. In the process, they can not only explore the theories that are at the foundation of management fads, determining their veracity, they can also play a role in improving the performance of organizations, and ask a question that is particularly pressing for the paradigm - would executives go for innovations that are mere window-dressing if they knew better?

We offer a theory of organizational change wherein innovations that turn managers into change agents are effective while those that seek to constrain managers and control their discretion will lead to resistance to program goals. This theory is in keeping with research on new work practices oriented to commitment, and research on empowerment. Unfortunately, in the field of diversity 
management, more firms have programs that constrain managers and control discretion than have programs that engage managers or create social accountability. Taskforces and diversity managers activate both engagement and accountability, but only $20 \%$ of medium and large employers have taskforces, and just $10 \%$ have diversity managers. Efforts to control managers' thinking and decision-making are more common. Nearly half of firms have diversity training; over half have formal grievance systems. We have been arguing that firms have adopted the wrong policies not with malice aforethought, but because they were clueless. The question is, now that the research is beginning to provide a clearer picture of which diversity programs are effective, will employers flock to those that work, or to those that don't?

\section{Notes}

1 http://newsroom.fb.com/news/2015/06/ driving-diversity-at-facebook/; www.google. com/diversity/

2 www.eeoc.gov/eeoc/initiatives/e-race/best practices-employers.cfm.

\section{REFERENCES}

Anderson, Bernard E. (1996). The ebb and flow of enforcing Executive Order 11246. American Economic Review, 86(2): 298-301.

Baron, James N. and Bielby, William T. (1980). Bringing the firms back in: Stratification, segmentation, and the organization of work. American Sociological Review, 45(5): 737-765.

Baron, James N. and Pfeffer, Jeffrey (1994). The social psychology of organizations and inequality. Social Psychology Quarterly, 57(3): 190-209.

Bem, Daryl J. (1972). Self-perception theory. In L. Berkowitz (ed.), Advances in Experimental Social Psychology. New York, NY: Academic Press. pp. 1-62.

Bendick, Mark, Egan, Mary Lou and Lofhjelm, Suzanne M. (1998). The Documentation and Evaluation of Anti-Discrimination Training in the United States. Washington, DC: Bendick and Egan Economic Consultants.
Berry, Christopher A., Clark, Malissa A. and McClure, Tara K. (2011). Racial/ethnic differences in the criterion-related validity of cognitive ability tests: a qualitative and quantitative review. Journal of Applied Psychology, 96(5): 881-906.

Bielby, William T. (2000). Minimizing workplace gender and racial bias. Contemporary Sociology, 29(1): 120-129.

Blumrosen, Alfred W. (1993). Modern Law: The Law Transmission System and Equal Employment Opportunity. Madison, WI: University of Wisconsin Press.

Bobo, Lawrence and Kluegel, James R. (1993). Opposition to race-targeting: Self-interest stratification ideology or racial attitudes. American Sociological Review, 58(4): 443-464.

Boyle, Barbara M. (1973). Equal opportunity for women is smart business. Harvard Business Review, 51: 85-95.

Brehm, S. S. and Brehm, J. W. (1981). Psychological Reactance: A Theory of Freedom and Control. New York, NY: Academic Press.

Bromley, Patricia and Powell, Walter W. (2012). From smoke and mirrors to walking the talk: Decoupling in the contemporary world. Academy of Management Annals, 6(1): 483-530.

Bureau of National Affairs. (1975). Paid Leave and Leave of Absence Policies. Vol. 111. Washington, DC: Bureau of National Affairs.

Burt, Ronald S. (1998). The gender of social capital. Rationality and Society, 10(1): 5-46.

Castilla, Emilio J. (2008). Gender, race, and meritocracy in organizational careers. American Journal of Sociology, 113(6): 1479-1526.

Castilla, Emilio J. and Benard, Stephen (2010). The paradox of meritocracy in organizations. Administrative Science Quarterly, 55(4): 543-576.

Chen, Anthony S. (2009). The Fifth Freedom: Jobs, Politics, and Civil Rights in the United States, 1941-72. Princeton, NJ: Princeton University Press.

Cohen, Philip N. and Huffman, Matt L. (2007). Working for the woman? Female managers and the gender wage gap. American Sociological Review, 72(5): 681-704.

Conference Board. (1992). In diversity is strength: Capitalizing on the new work force. 75th Anniversary Symposia Series. Report Number 994 (edited by J. Alster, T. Brothers and H. Gallo). New York: Conference Board, Inc.

Cooper, Joel and Fazio, Russell H. (1984). A new look at dissonance theory. Advances in Experimental Social Psychology, 17: 229-266.

Cottrell, Nicholas (1972). Social Facilitation. In C. McClintock (ed.), Experimental Social Psychology. New York, NY: Holt, Rinehart \& Winston. pp. 185-236. 
Davis, Gerald F. and Greve, Henrich (1997). Corporate elite networks and governance changes in the 1980s. American Journal of Sociology, 103(1): $1-37$.

Deitch, Cynthia H. and Huffman, Matt L. (2001). Family-responsive benefits and the two-tiered labor market. In R. Hertz and N. Marshall (eds), Working Families: The Transformation of the American Home. Berkeley, CA: University of California Press. pp. 103-130.

Dobbin, Frank (2009). Inventing Equal Opportunity. Princeton, NJ: Princeton University Press.

Dobbin, Frank and Kalev, Alexandra (2015). Why firms need diversity managers and task forces. In M. Pilati, H. Sheikh, F. Sperotti and C. Tilly (eds), How Global Migration Changes the Workforce Diversity Equation. Newcastle upon Tyne: Cambridge Scholars. pp. 170-198.

Dobbin, Frank, Kalev, Alexandra and Kelly, Erin (2007). Diversity management in corporate America. Contexts, 6(4): 21-28.

Dobbin, Frank and Kelly, Erin (2007). How to stop harassment: The professional construction of legal compliance in organizations. American Journal of Sociology, 112(4): 1203-1243.

Dobbin, Frank, Kim, Soohan and Kalev, Alexandra (2011). You can't always get what you need: Why diverse firms adopt diversity programs. American Sociological Review, 76(3): 386-411.

Dobbin, Frank, Schrage, Daniel and Kalev, Alexandra (2015). Rage against the iron cage: The varied effects of bureaucratic personnel reforms on diversity. American Sociological Review, 80(5): 1014-1044

Dobbin, Frank and Sutton, John R. (1998). The strength of a weak state: The employment rights revolution and the rise of human resources management divisions. American Journal of Sociology, 104(2): 441-476

Dobbin, Frank, Sutton, John R., Meyer, John W. and Scott, W. Richard (1993). Equal opportunity law and the construction of internal labor markets. American Journal of Sociology, 99(2): 396-427.

Edelman, Lauren B. (1990). Legal environments and organizational governance: The expansion of due process in the American workplace. American Journal of Sociology, 95(6): 1401-1440.

Edelman, Lauren B. (1992). Legal ambiguity and symbolic structures: Organizational mediation of civil rights law. American Journal of Sociology, 97(6): 1531-1576.

Edelman, Lauren B., Fuller, Sally Riggs and MaraDrita, Iona. (2001). Diversity Rhetoric and the managerialization of the law. American Journal of Sociology, 106(6): 1589-1641.

Edelman, Lauren B., Krieger, Linda H., Eliason, Scott, Albiston, Catherine R. and Mellema, Virginia
(2011). When organizations rule: Judicial deference to institutionalized employment structures. American Journal of Sociology, 117(3): 888-954.

Edelman, Lauren B. and Petterson, Stephen M. (1999). Symbols and substance in organizations response to civil rights law. Research in Social Stratification and Mobility, 17: 107-135.

Edelman, Lauren B., Uggen, Christopher and Erlanger, Howard S. (1999). The endogeneity of legal regulation: Grievance procedures as rational myth. American Journal of Sociology, 105(2): 406-454.

Fernandez, Roberto M. and Fernandez-Mateo, Isabel (2006). Network, race, and hiring. American Sociological Review, 71(1): 42-71.

Festinger, Leon (1957). A theory of cognitive dissonance. Stanford, CA: Stanford University Press.

Festinger, Leon and Carlsmith, James M. (1959). Cognitive consequences of forced compliance. Journal of Abnormal and Social Psychology, 58(2): 203-210.

Fiske, Susan T. (1998). Stereotyping, prejudice and discrimination. In D. T. Gilbert, S. T. Fiske and G. Lindzey (eds), The Handbook of Social Psychology, 4th edn, volume 2. New York: McGraw Hill. pp. 357-411.

Galinsky, Adam D. and Moskowitz, Gordon B. (2000). Perspective taking: decreasing stereotype expression stereotype accessibility, and in-group favoritism. Journal of Personality and Social Psychology, 78(4): 708-724.

Gordon, Hugh L. (2000). Cobb County Oral History Series No. 75. Interview with Hugh L. Gordon conducted by Joyce A. Patterson.

Gorman, Elizabeth (2005). Gender stereotypes, same-gender preferences, and organizational variation in the hiring of women: Evidence from law firms. American Sociological Review, 70(4): 702-728.

Gouldner, Alvin W. (1954). Patterns of industrial democracy: A case study of modern factory administration. New York, NY: Free Press.

Graham, Hugh Davis (1990). The Civil Rights Era: Origins and Development of National Policy, 1960-1972. New York: Oxford University Press.

Granovetter, Mark (1974). Getting a Job: A Study of Contracts and Careers. Chicago, IL: University of Chicago Press.

Guthrie, Douglas and Roth, Louise Marie (1999). Family-friendly policies in U.S. organizations: Institutional environments and maternity leave. American Sociological Review, 64(1): 41-63.

Hamner, W. Clay, Kim, Jay S., Baird, Lloyd, and Bigoness, William J. (1974). Race and sex as determinants of ratings by potential employers in a simulated work-sampling task. Journal of Applied Psychology, 59(6): 705-712. 
Hegewisch, Ariane, Deitch, Cynthia H. and Murphy, Evelyn F. (2011). Ending sex and race discrimination in the workplace: Legal interventions that push the envelope. Washington, D.C.: Institute for Women's Policy Research.

Heilman, Madeline (1995). Sex stereotypes and their effects in the workplace: What we know and what we don't know. Journal of Social Behavior and Personality, 10(6): 3-26.

Hirsh, Elizabeth and Kmec, Julie A. (2009). Human resource structures: Reducing discrimination or raising rights awareness? Industrial Relations: A Journal of Economy and Society, 48(3): 512-532.

Hodson, Randy (1991a). Workplace behaviors: Good soldiers, smooth operators, and saboteurs. Work and Occupations, 18(3): 271-290.

Hodson, Randy (1991b). The active worker: Compliance and autonomy at the workplace. Journal of Contemporary Ethnography, 20(1): 47-78.

Hodson, Randy (1996). Dignity in the workplace under participative management: Alienation and Freedom Revisited. American Sociological Review, 61(5): 719-738.

Holzer, Harry J. and Neumark, David (2000). What does affirmative action do? Industrial and Labor Relations Review, 53(2): 240-271.

Ibarra, Herminia (1995). Race, opportunity and diversity of social circles in managerial networks. Academy of Management Journal, 38(3): 673-703.

Ito, Tiffany A., Chiao, Krystal W., Devine, Patricia G. Lorig, Tyler S., and Cacioppo, John T. (2006). The influence of facial feedback on race bias. Psychological Science, 17(3): 256-261.

Jacoby, Sanford (1984). The development of internal labor markets in American manufacturing firms. In P. Osterman (ed.), Internal Labor Markets. Cambridge, MA: MIT Press. pp. 23-69.

Johnson, Cathryn, Dowd, Timothy J. and Ridgeway, Cecilia L. (2006). Legitimacy as a social process. Annual Review of Sociology, 32(1): 53-78.

Judge, Timothy A., Thoresen, Carl. J., Bono, Joyce E., and Patton, Gregory K. (2001). The job satisfactionjob performance relationship: A qualitative and quantitative review. Psychological Bulletin, 127(3): 376-407.

Jung, Jiwook and Dobbin, Frank (2016). Agency theory as prophecy: How boards, analysts, and fund managers perform their roles. Seattle University Law Review, 39(2): 291-320.

Kaiser, Cheryl R., Major, Brenda, Ines, Jurcevic, Dover, Tessa L., Brady, Laura M. and Shapiro, Jenessa R. (2013). Presumed fair: Ironic effects of organizational diversity structures. Journal of Personality and Social Psychology, 104(3): 504-519.

Kalev, Alexandra and Dobbin, Frank (2006). Enforcement of civil rights law in private workplaces: The effects of compliance reviews and lawsuits over time. Law and Social Inquiry, 31(4): 855-879.

Kalev, Alexandra, Dobbin, Frank and Kelly, Erin (2006). Best practices or best guesses? Assessing the efficacy of corporate affirmative action and diversity policies. American Sociological Review, 71(4): 589-617.

Kamerman, Sheila B., Kahn, Alfred J. and Kingston, Paul (1983). Maternity Policies and Working Women. New York: Columbia University Press.

Kanter, Rosabeth Moss. (1977). Men and Women of the Corporation. New York: Basic Books.

Kelly, Erin A. (2003). The strange history of employersponsored childcare: Interested actors, uncertainty, and the transformation of law in organizational fields. American Journal of Sociology, 109(3): 606-649.

Kelly, Erin A. and Dobbin, Frank (1998). How affirmative action became diversity management. American Behavioral Scientist, 41(7): 960-984.

Kelly, Erin and Dobbin, Frank (1999). Civil rights law at work: Sex discrimination and the rise of maternity leave policies. American Journal of Sociology, 105(2): 455-492.

Kelly, Erin L., Moen, Phyllis and Tranby, Eric (2011). Changing workplaces to reduce work-family conflict: schedule control in a white-collar organization. American Sociological Review, 76(2): 265-290.

Kidder, Deborah L., Lankau, Melenie J., ChrobotMason, Donna, Mollica, Kelly A. and Friedman, Raymond A. (2004). Backlash toward diversity initiatives: Examining the impact of diversity program justification, personal and group outcomes. International Journal of Conflict Management, 15(1): 77-104.

Kochan, Thomas A., Katz, Harry C., and McKersie, Robert B. (1994). The transformation of American industrial relations. Ithaca, NY: ILR Press.

Konrad, Alison M. and Linnehan, Frank (1995). Formalized HRM structures - coordinating equalemployment opportunity or concealing organizational practices. Academy of Management Journal, 38(3): 787-820.

Kraiger, Kurt and Ford, J. Kevin (1985). A metaanalysis of ratee race effects in performance ratings. Journal of Applied Psychology, 70(1): 56-65.

Kruglanski, Arie W. and Freund, Tallie (1983). The freezing and unfreezing of lay-inferences: Effects on impressional primacy, ethnic stereotyping, and numeral anchoring. Journal of Experiemental Social Psychology, 19(5): 448-468.

Lamont, Michèle (2000). The dignity of working men: Morality and the boundaries of cass, race, and immigration. Cambridge, MA: Harvard University Press. 
Legault, Lisa, Gutsell, Jennifer N. and Inzlicht, Michael (2011). Ironic effects of antiprejudice messages: How motivational interventions can reduce (but also increase) prejudice. Psychological Science, 22: 1472-1477.

Lemm, Kristi and Banaji, Mahzarin R. (1999). Unconscious attitudes and beliefs about men and women. In U. Pasero and F. Braun (eds), Perceiving and Performing Gender. Opladen: Westdutscher Verlag. pp. 215-235.

Leonard, Jonathan S. (1989). Women and affirmative action. The Journal of Economic Perspectives, 3(1): $61-75$.

Leonard, Jonathan S. (1990). The impact of affirmative action regulation and equal employment opportunity law on black employment. Journal of Economic Perspectives, 4(4): 47-63.

Lerner, Jennifer S. and Tetlock, Philip E. (1999). Accounting for the effects of accountability. Psychological Bulletin, 125(2): 255-275.

Lieberman, Robert C. (2002). Weak state, strong policy: Paradoxes of race policy in the United States, Great Britain, and France. Studies in American Political Development, 16(2): 138-161.

Mattison, E. G. (1965). Integrating the work force in Southern industry. In H. R. Northrup and R. L. Rowan (eds), The Negro and Employment Opportunity: Problems and Practices. Ann Arbor, Ml: Bureau of Industrial Relations, Graduate School of Business Administration, University of Michigan. pp. 147-54.

McKay, Patrick F. and McDaniel, Michael A. (2006). A reexamination of black-white mean differences in work performance: More data, more moderators. Journal of Applied Psychology, 91(3): 538-554.

Meyer, John W. and Rowan, Brian (1977). Institutionalized organizations: Formal structure as myth and ceremony. American Journal of Sociology, 83(2): 340-363.

Miller, Joanne (1994). Corporate Responses to Diversity. Queens College, New York.

Mong, Sherry and Roscigno, Vincent J. (2010). African American men and the experience of employment discrimination. Qualitative Sociology, 33(1): $1-21$.

Mori, Hideko and Mori, Kazuo (2013). An implicit assessment of the effect of artificial cheek raising: When your face smiles, the world looks nicer. Perceptual and Motor Skills, 116(2): 466-471.

Naff, Katherine C. and Kellough, J. Edward (2003). Ensuring employment equity: Are federal diversity programs making a difference? International Journal of Public Administration, 26(12): 1307-1336.

Nelson, Robert L. and Bridges, William P. (1999). Legalizing Gender Inequality: Courts, Markets and Unequal Pay for Women in America. New York, NY: Cambridge University Press.
Nelson, Thomas E., Acker, Michele and Melvin, Manis (1996). Irrepressible stereotypes. Journal of Experimental Social Psychology, 32(1): 13-38.

Neumark, David and Gardecki, Rosella (1996). Women Helping Women? Role-Model and Mentoring Effects on Female Ph.D. Student in Economics. Cambridge, MA: National Bureau of Economic Research.

Nonet, Philippe and Selznick, Philip (1978). Law and Society in Transition: Toward Responsive Law. New York: Octagon Books.

Oppler, Scott H., Campbell, John P., Pulakos, Elaine D. and Borman, Walter C. (1992). Three Approaches to the investigation of subgroup bias in performance measurement: Review, results, and conclusions. Journal of Applied Psychology, 77(2): 201-217.

Paluck, Elizabeth L. and Green, Donald P. (2009). Prejudice reduction: What works? A critical look at evidence from the field and the laboratory. Annual Review of Psychology, 60: 339-367.

Pernell, Kim, Jung, Jiwook and Dobbin, Frank (forthcoming). Doubling down on derivatives: Chief risk officers, CEOs, and fund managers. American Sociological Review.

Petersen, Trond, Saporta, Ishak and Seidelm, Marc David (1998). Offering a job: Meritocracy and social networks. American Journal of Sociology, 106: 763-816.

Pfeffer, Jeffrey and Sutton, Robert I. (2006). Hard Facts, Dangerous Half-Truth and Total Nonsense: Profiting from Evidence-Based Management. Cambridge, MA: Harvard Business School Press.

Plant, E. Ashby and Devine, Patricia G. (2001). Responses to other-imposed pro-Black pressure: Acceptance or backlash? Journal of Experimental Social Psychology, 37(6): 486-501.

Pulakos, Elaine D., White, Leonard A., Oppler, Scott H., and Borman, Walter C. (1989). Examination of race and sex effects on performance ratings. Journal of Applied Psychology, 74(5): 770-780.

Puma, John J. (1966). Improving Negro employment in Boston. Industrial Management Review, 8(1): 37-45.

Purcell, Theodore V. (1953). The Worker Speaks His Mind on Union and Company, Vol. 52. Cambridge, MA: Harvard University Press.

Reskin, Barbara F. (2003). Including mechanisms in our models of ascriptive inequality. American Sociological Review, 68(1): 1-21.

Reskin, Barbara F. and McBrier, Debra B. (2000). Why not ascription? Organizations' employment of male and female managers. American Sociological Review, 65(2): 210-233.

Reskin, Barbara F. and Roos, Patricia (1990). Job Queues, Gender Queues: Explaining Women's 
Inroads into Male Occupations. Philadelphia, PA: Temple University Press.

Rivera, Lauren A. (2015). Pedigree: How Elite Students Get Elite Jobs. Princeton, NJ: Princeton University Press.

Roche, Gerard R. (1979). Much ado about mentors. Harvard Business Review, 57(1): 14-20.

Rodriguez, Robert (2007). Latino Talent: Effective Strategies to Recruit, Retain and Develop Hispanic Professionals. New York: Wiley.

Roos, Patricia and Manley, Joan E. (1996). Staffing personnel: Feminization and change in human resource management. Sociological Focus, 99(3): 245-261.

Roth, Philip L., Huffcutt, Allen I. and Bobko, Philip (2003). Ethnic group differences in measures of job performance: A new meta-analysis. Journal of Applied Psychology, 88(4): 694-706.

Roy, Donald (1952). Quota restriction and goldbricking in a machine shop. American Journal of Socio/ogy, 57(5): 427-442.

Ruhm, Christopher J. and Teague, Jackqueline L. (1997). Parental leave policies in Europe and North America. In F. D. Blau and R. G. Ehrenberg (eds), Gender and Family Issues in the Workplace. New York: Russell Sage Foundation. pp. 133-156.

Rynes, Sara and Rosen, Benson (1995). A field survey of factors affecting the adoption and perceived success of diversity training. Personnel Psychology, 48(2): 247-270.

Schlanger, Margo and Kim, Pauline (2014). The Equal Employment Opportunity Commission and structural reform of the American workplace. Washington University Law Review, 91(6): 1519-1590.

Shaeffer, Ruth G. (1973). Nondiscrimination in Employment: Changing Perspectives, 1963-1972. New York: The Conference Board.

Shwed, Uri and Kalev, Alexandra (2014). Are referrals more productive or more likable? Social networks and the evaluation of merit. American Behavioral Scientist, 58: 288-308.

Sidanius, Jim, Devereux, Erik and Pratto, Felicia (2001). A comparison of symbolic racism theory and social dominance theory as explanations for racial policy attitudes. Journal of Social Psychology, 132(3): 377-395.

Silvia, Paul J. (2005). Deflecting reactance: The role of similarity in increasing compliance and reducing resistance. Basic and Applied Social Psychology, 27(3): 277-284.

Steeh, Charlotte and Krysan, Maria (1996). The polls - trends: Affirmative action and the public, 1970-1995. Public Opinion Quarterly, 60(1): 128-158.

Strang, David (2010). Learning by Example: Imitation and Innovation at a Global Bank. Princeton, NJ: Princeton University Press.

Strang, David and Meyer, John W. (1993). Institutional conditions for diffusion. Theory and Society, 22(4): 487-511.

Stryker, Robin (1996). Law sociology and public policy issues in equal employment opportunity. Paper presented at the Annual Meeting of the American Sociological Association.

Sturm, Susan (2001). Second generation employment discrimination: A structural approach. Columbia Law Review, 101(3): 459-568.

Tetlock, Philip E. (1985). Accountability: A social check on the fundamental attribution error. Social Psychology Quarterly, 48(3): 227-436.

Tetlock, Philip E. (1992). The impact of accountability on judgment and choice: Toward a social contingency model. In M. Zanna (ed.), Advances in Experimental Social Psychology. New York, NY: Academic Press. pp. 331-376.

Thomas, David A. (2001). The truth about mentoring minorities: Race matters. Harvard Business Review, April: 99-107.

Tsui, Anne S. and Gutek, Barbara A. (1984). A role set analysis of gender differences in performance, affective relationships, and career success of industrial middle managers. Academy of Management Journal, 27(3): 619-635.

Vernon-Gerstenfeld, Susan and Burke, Edmund (1985). Affirmative action in nine large companies: A field study. Personnel, 62(4): 54-60.

Yermack, David (1996). Higher market valuation of companies with a small board of directors. Journal of Financial Economics, 40(2): 185-211.

Zanna, Mark P. and Cooper, Joel (1974). Dissonance and the pill: An attribution approach to studying the arousal properties of dissonance. Journal of Personality and Social Psychology, 29(5): 703-709.

Zuckerman, Ezra W. (1999). The categorical imperative: Securities analysts and the illegitimacy discount. American Journal of Sociology, 104(5): 1398-1438. 